\title{
Nucleolar organiser region associated proteins in cutaneous melanotic lesions: a quantitative study
}

\author{
J CROCKER, N SKILBECK
}

From the Department of Histopathology, East Birmingham Hospital, Bordesley Green East, Birmingham

\begin{abstract}
SUMMARY Using a silver staining technique, nucleolar organiser regions were identified in routinely processed paraffin sections of a range of dermal melanotic lesions. The technique shows argyrophilic NOR associated proteins (AgNORs), which are seen in nuclei as black dots. Although the nuclei of melanocarcinoma in situ, melanocarcinoma per se, and lentigo maligna contained similar numbers of AgNORs, in melanocarcinomas a mean of 7.9 AgNORs per nucleus was found, while in naevocellular naevi, this figure was 1·2. The AgNOR method, which is unknown to most histopathologists, could perhaps be used quantitatively or semiquantitatively to assist in the diagnosis of melanotic lesions in the skin (and elsewhere).
\end{abstract}

Nucleolar organiser regions (NORs) are loops of ribosomal DNA (rDNA) which occur in nucleoli and ultimately direct ribosome and protein formation. The NOR DNA possesses ribosomal RNA (rRNA) genes which are transcribed by RNA polymerase $\mathrm{I}^{1{ }^{1}}$ NOR-associated proteins and NORs themselves have been visualised in the past by cytogeneticists using a simple argyrophilic (AgNOR) technique. ${ }^{3}$ This has been used for the detection of certain trisomiesnotably, that of chromosome $21 .{ }^{4}$ More recently, it has been suggested that the numbers of AgNORs in nuclei may reflect their state of activation or, indeed, malignancy. ${ }^{5}$

In view of these findings NORs have recently been studied in malignant lymphomas using a silver staining (AgNOR) technique. ${ }^{6}$ This showed that the numbers of demonstrable NORs in paraffin sections of lymphomas reflected their degree of (histological) malignancy. Accordingly, we applied the method to another field of histopathology where the assessment of malignancy may be difficult-namely that of melanotic skin lesions.

\section{Material and methods}

Fifty melanotic skin lesions were studied. These comprised: 10 melanocarcinomas, 10 intradermal naevocellular naevi, 10 compound naevocellular naevi, five junctional naevi, five superficial spreading melanomas, three cases of lentigo maligna, two of cel-

Accepted for publication 6 April 1987 lular blue naevus and five juvenile melanomas. These were taken from routine files at this hospital. They had been fixed in $10 \%$ formalin and processed to paraffin wax. Sections were cut at $3 \mu \mathrm{m}$ thickness and were taken to water via xylene and graded ethanols.

The sections were submitted to the AgNOR procedure at room temperature for 30 minutes. The reaction mixture comprised $2 \%$ gelatin in $1 \%$ aqueous formic acid. This was mixed in a proportion of $1: 2$ volumes with $50 \%$ aqueous silver nitrate under dark room conditions. After staining the mixture was poured from the slides. Counterstaining was not performed, and the sections were dehydrated to xylene and mounted in synthetic medium.

Sections were examined under an oil immersion lens at a magnification of 1000 , and 100 nuclei were studied. The AgNOR "dots" in these were counted by a simple eyepiece graticule (to prevent recounting). Preliminary experiments showed this method to be no more time consuming than the use of a semiautomatic image analyser. The mean number of AgNORs per nucleus was calculated for each specimen. In all cases the AgNORs in randomly selected naevus or melanocarcinoma cells were counted. The AgNORs in adjacent normal epidermis, adnexae, and lymphocytes were not included.

\section{Results}

In all specimens AgNORs were clearly visible as black dots of varying sizes in the nuclei. In general, these were present over nucleoli, but often smaller 
AgNORs could be seen lying away from main nucleolar structures. The AgNORs were easily counted. Cytoplasmic melanin, where present, was stained black; this did not obscure nuclear AgNORs.

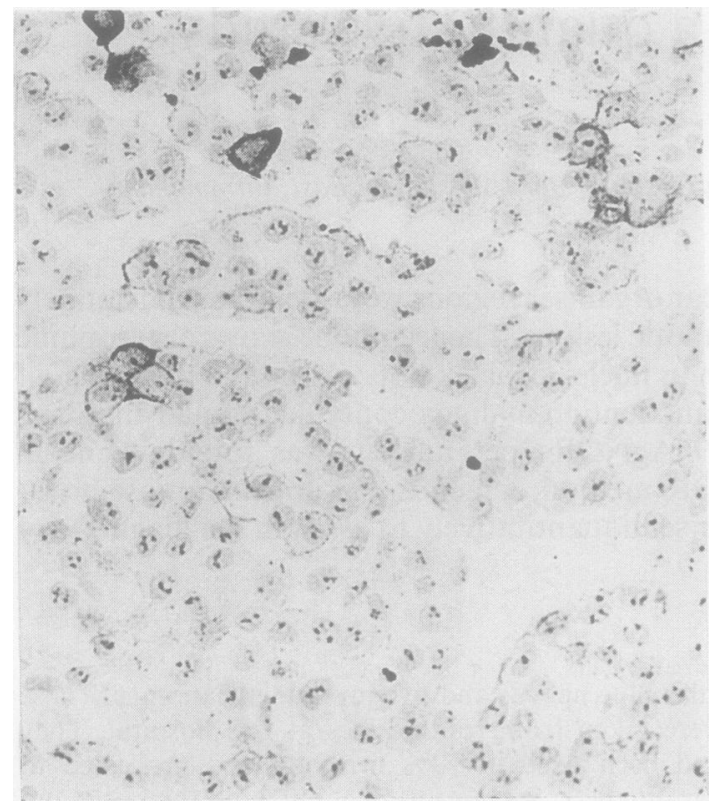

Fig 1 Melanocarcinoma. All cells contain multiple black nuclear dots. Melanin pigment is present in some cells. (AgNOR reaction; no counterstain.)
The highest numbers of AgNORs were seen in melanocarcinomas (7.1-11.6; mean 8.23; SEM 0.57) and in superficial spreading melanomas (5.8-10.1; mean 8.06; SEM 0.78) (figs 1 and 2). Where lympho-

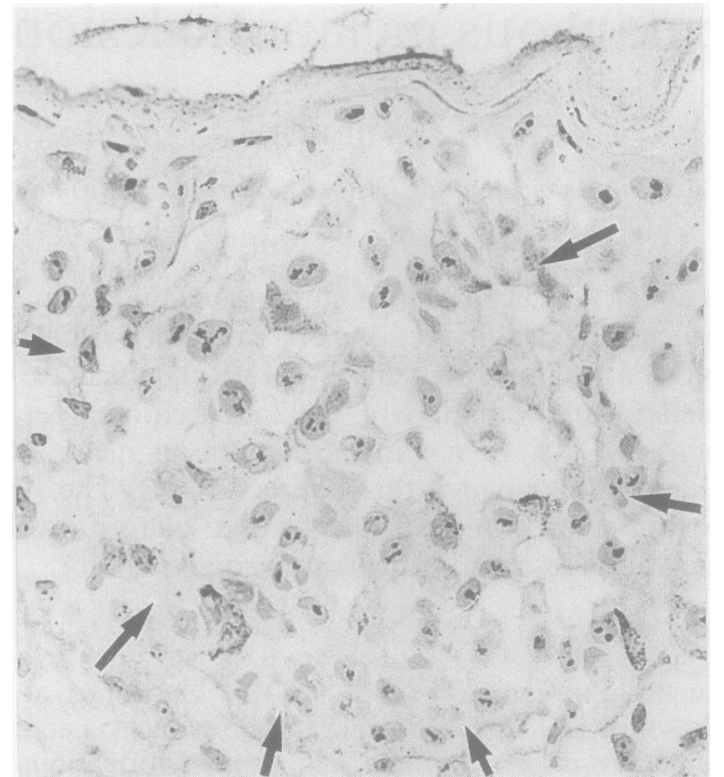

Fig 2 Epidermis containing malignant melanocytic infiltrate. Malignant cells contain multiple nuclear dots. (Malignant cluster outlined by arrows.) (AgNOR reaction; no counterstain.)

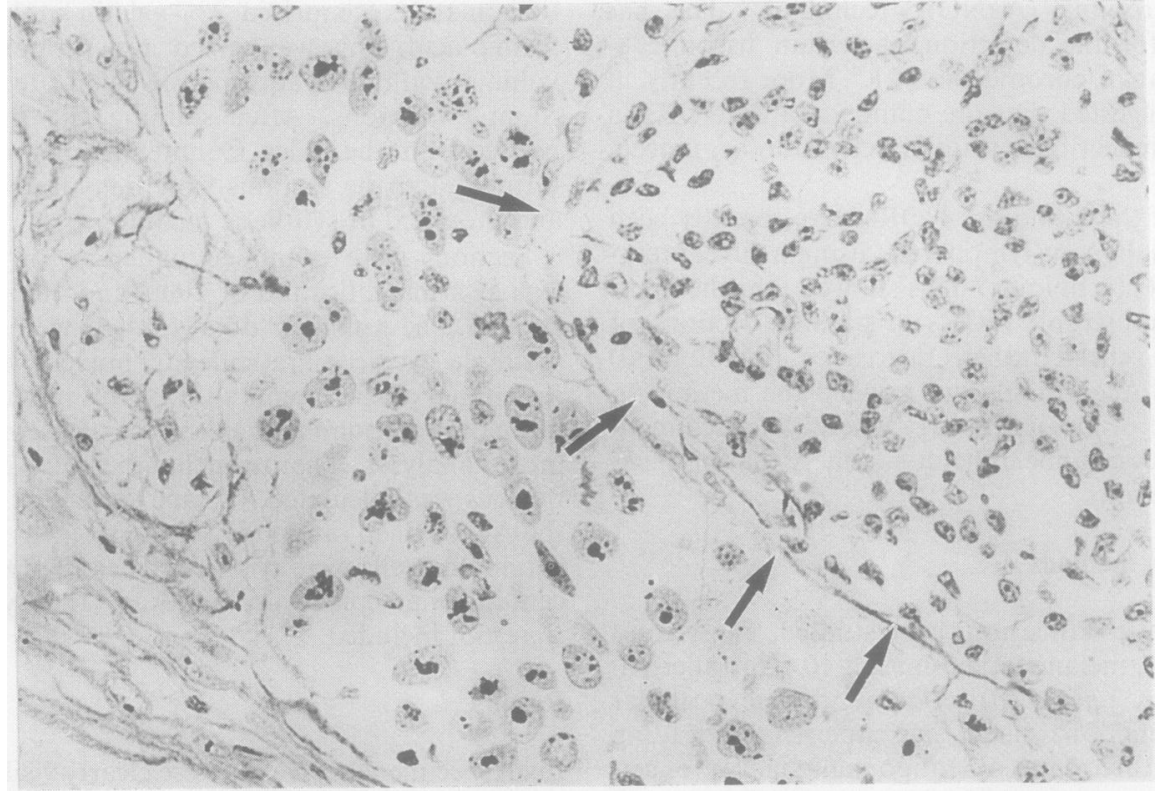

Fig 3 Melanocarcinoma, nuclei of which bear multiple black dots. Adjacent lymphocytic infiltrate is outlined by arrows; lymphocytes possess only one or two dots. (AgNOR reaction; no counterstain.) 


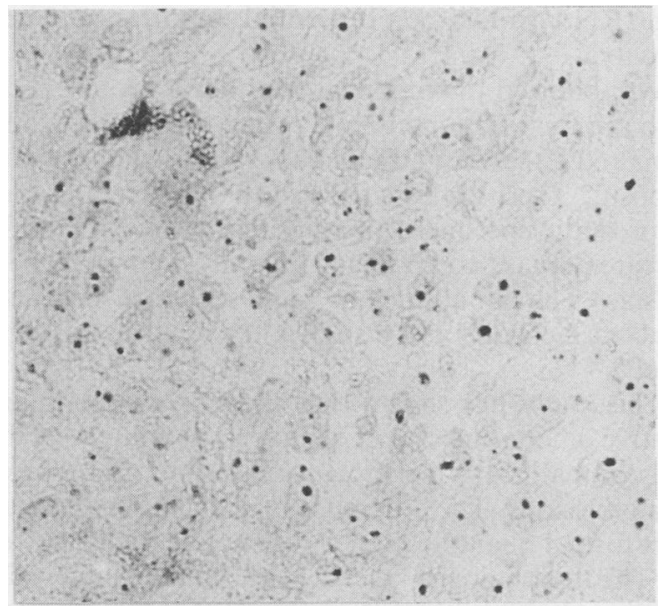

Fig 4 Intradermal naevocellular naevus cells each bearing only one or two dots. (AgNOR reaction; no counterstain.)

cytes were observed in association with these lesions, they possessed only a mean of $1 \cdot 1$ AgNOR per nucleus. (fig 3) Lentigo maligna also showed numerous AgNORs (5.8-9.1; mean 7.4; SEM 0.94). In striking contrast, intradermal naevi $(0.8-1.5$; mean $1 \cdot 16$; SEM 0.07) (fig 4), compound naevi $(0.8-1.4$; mean $1 \cdot 1$; SEM 0.06), junctional naevi (1.0-1.4; mean 1.18; SEM 0.08) (fig 5), cellular blue juvenile melanomas (1.2-1.3; mean 1.25; SEM 0.05), and juvenile melanomas (1.0-1.6; mean 1.36; SEM 0.1) possessed strikingly fewer AgNORs than the malignant lesions. Where naevus cells were large or "giant" they possessed two or three AgNORs but, of course, the mean AgNOR count was not affected by these occasional cells.

The pooled mean AgNOR numbers per nucleus for the benign group of lesions was 1.21 and for the malignant group 7.9 (significance of difference

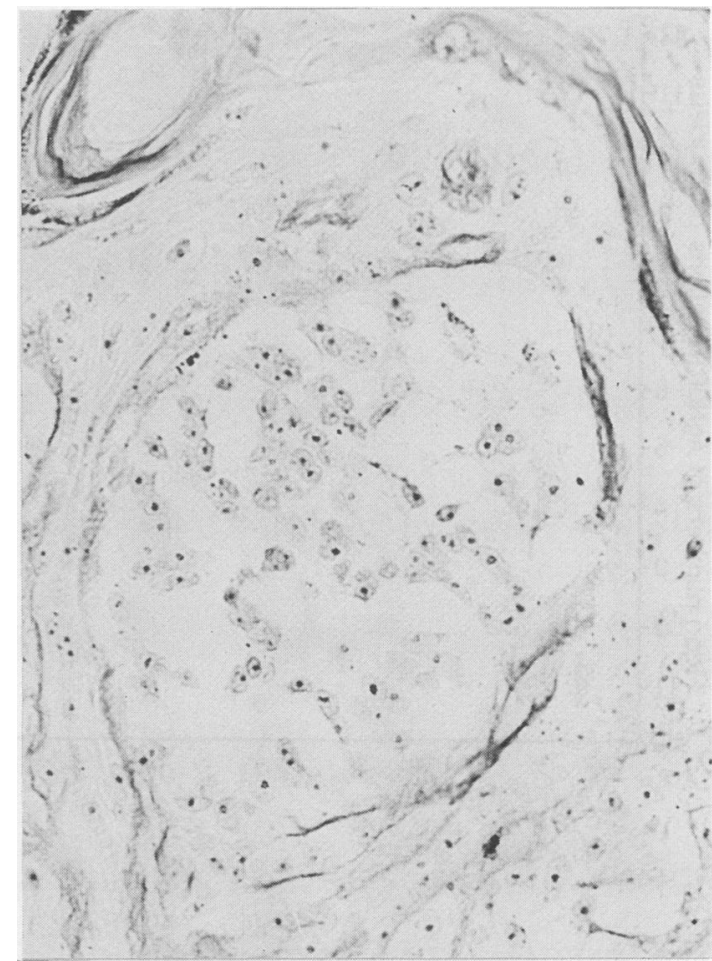

Fig 5 Naevus cells in epidermis. In contrast to malignant cells in fig 2, these possess only one or two dots. (AgNOR reaction; no counterstain.)

$\mathrm{p}>0.001$, Student's $t$ test). In the normal adjacent epidermis the basal layer cells possessed three to four AgNORs per nucleus. As maturation occurred towards the surface, this number declined to one AgNOR per nucleus. The basal cells were readily distinguished from the malignant melanocytes in the epidermis (table, fig 6).

Table Ranges and mean Nos of AgNORs per nucleus in the skin lesions studied

\begin{tabular}{|c|c|c|c|c|c|c|c|c|}
\hline Case Nos & $\begin{array}{l}\text { Intradermal } \\
\text { naevocellular } \\
\text { naevus }\end{array}$ & $\begin{array}{l}\text { Compound } \\
\text { naevocellular } \\
\text { naevus }\end{array}$ & $\begin{array}{l}\text { Junctional } \\
\text { naevocellular } \\
\text { naevus }\end{array}$ & $\begin{array}{l}\text { Cellular } \\
\text { blue } \\
\text { naevus }\end{array}$ & $\begin{array}{l}\text { Juvenile } \\
\text { melanoma }\end{array}$ & $\begin{array}{l}\text { Lentigo } \\
\text { maligna }\end{array}$ & $\begin{array}{l}\text { Superficial } \\
\text { spreading } \\
\text { melanoma }\end{array}$ & Melanocarcinoma \\
\hline $\begin{array}{c}1 \\
2 \\
3 \\
4 \\
5 \\
6 \\
7 \\
8 \\
9 \\
10 \\
\text { Mean } \\
\text { SD } \\
\text { SEM }\end{array}$ & $\begin{array}{l}1 \cdot 1 \\
1.2 \\
1.0 \\
0.9 \\
1.4 \\
1.3 \\
1 \cdot 1 \\
0 \cdot 8 \\
1.3 \\
1.5 \\
1.16 \\
0.22 \\
0.07\end{array}$ & $\begin{array}{l}1.0 \\
1.4 \\
1.1 \\
0.8 \\
1.3 \\
1.4 \\
1.1 \\
0.9 \\
1.0 \\
1.0 \\
1.1 \\
0.21 \\
0.06\end{array}$ & $\begin{array}{l}1.3 \\
1.2 \\
1.0 \\
1.0 \\
1.4\end{array}$ & $\begin{array}{l}1.25 \\
0.07 \\
0.05\end{array}$ & $\begin{array}{l}1.6 \\
1.4 \\
1.0 \\
1.3 \\
1.5\end{array}$ & $\begin{array}{l}5 \cdot 8 \\
9 \cdot 1 \\
7 \cdot 3\end{array}$ & $\begin{array}{r}6.7 \\
8.9 \\
10.1 \\
5.8 \\
8.8\end{array}$ & $\begin{array}{r}7.5 \\
4.2 \\
7.9 \\
8.5 \\
8.5 \\
11.6 \\
7.1 \\
8.8 \\
9.2 \\
9.0 \\
8.23 \\
1.87 \\
0.57\end{array}$ \\
\hline
\end{tabular}




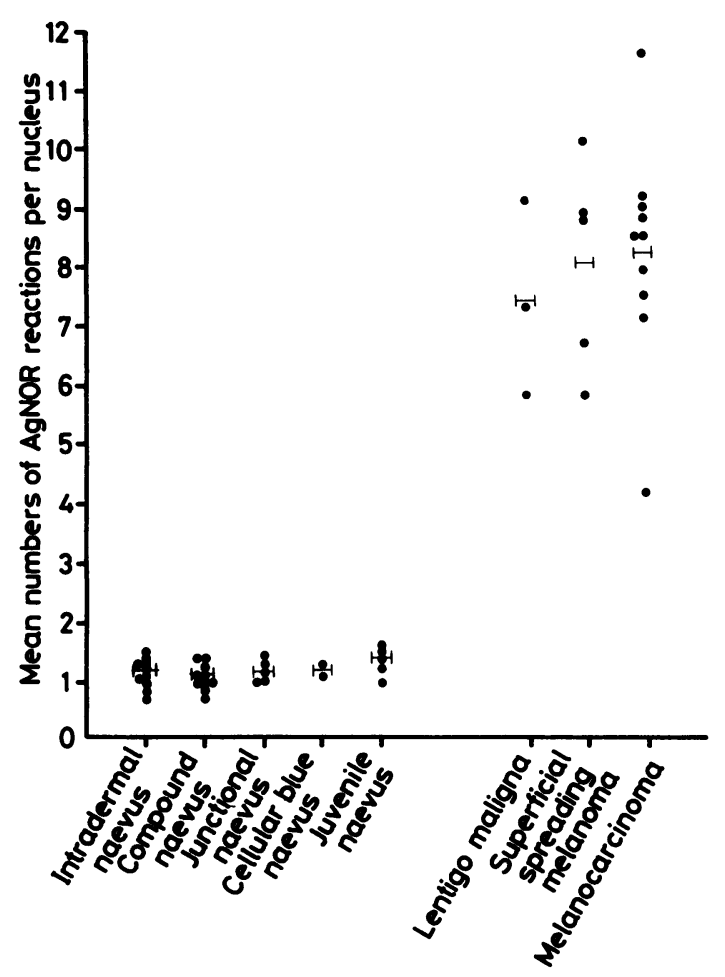

Fig 6 Distribution of mean AgNOR numbers per nucleus for specimens examined.

\section{Discussion}

Despite its use and recognition as a cytogenetic technique for over a decade, the AgNOR technique has only very recently been applied in histopathology. ${ }^{6}$ The presence of NORs on the short arms of five acrocentric chromosome pairs in man (as in certain primates)-namely, chromosomes 13, 14, 15, 21 and 22 has enabled trisomies to be detected in metaphase spread. In man each NOR possesses about 40 transcription units ${ }^{7}$ which has been shown by hybridisation studies. The argyrophilic NOR-associated proteins shown by the AgNOR method are not fully characterised; they may correspond to RNA polymerase $I^{8}$ or to " $C_{23}$ protein". 910 They seem to regulate rDNA transcription ${ }^{11}$ or maintain rDNA in extended form, ${ }^{12}$ or both.

Initial studies of the numbers of AgNORs in certain cell types, such as HL60 promyelocytes, K562 cells, and sections of prostate suggested that these numbers reflected cell activity or even neoplasia. This seems to be the case in lymphoid tissue sections. ${ }^{6} \mathrm{~A}$ relation between AgNORs and thus NORs themselves might be expected as the transcription of rDNA and rRNA should be of essential importance in cell activity.

We followed the modified method of Ploton et al, who ran the reaction at $20^{\circ} \mathrm{C}$ rather than at the traditional $60^{\circ} \mathrm{C}$ and found less background staining and deposit. ${ }^{5}$ These authors showed that in a small series of prostatic specimens there were multiple AgNORs in carcinomas, compared with only two in hyperplasias. The modified one step sequence has also enabled AgNORs to be shown at the ultrastructural level. ${ }^{1314}$

This study has shown that there is a clear quantitative difference between the AgNOR content of the cells of malignant melanotic skin lesions and that of benign lesions. The difference is of such a magnitude that formal quantification would not be necessary for the histopathologist faced with making the distinction. Indeed, it is not proposed that the reported figures are absolute as $3 \mu \mathrm{m}$ sections of much larger structures-that is, cell nuclei-have been studied. The distinction between benign and malignant lesions in this context is, of course, essential and may be difficult in routine sections. Interestingly, the cells of superficial spreading melanoma and lentigo maligna differed from the cells of, for example, junctional naevi in their AgNOR content as this is sometimes a difficult diagnostic area. The observation that the basal layer of normal epidermis possessed more AgNORs per nucleus than do the more superficial cells, agrees with similar findings reported for tonsillar epithelium. ${ }^{6}$

It may be that the numbers of AgNORs in a cell reflect its degree of ploidy. In view of the known numbers of chromosomes bearing AgNORs referred to above, ${ }^{5}$ however, it seems that, in view of the presence of only about one AgNOR in benign naevus cells and melanocytes, there is variable expression of NORassociated proteins. The possibility that NOR activity should be related to cellular activity and thus, perhaps, transformation and malignancy, has previously been noted. ${ }^{56}$

We thank Mrs Ruth Fry for wordprocessing and Mr MJ Chard for photographic help.

\section{References}

1 Alberts B, Bray D, Lewis J, Raff M, Roberts K, Watson JD. Molecular biology of the cell. New York: Garland Publishing, 1983:424-6.

2 Perry RP. Processing of RNA. Ann Rev Biochem 1976;45:605-29.

3 Howell WM, Black DA. Controlled silver staining of nucleolus organizer regions with a protective colloidal developer: a onestep method. Experientia 1960;36:1014.

4 de la Cruz FF, Gerald PS. Trisomy 21. Baltimore: University Park Press, 1981:165-7. 
5 Ploton D, Menager M, Jeannesson P, Himber G, Pigeon F, Adnet $\mathrm{JJ}$. Improvement in the staining and in the visualisation of the argyrophilic proteins of the nucleolar organizer region at the optical level. Histochem J 1986;18:5-14.

6 Crocker J, Nar P. Nucleolar organiser regions in lymphomas. $J$ Pathol 1987;151:111-8.

7 Lewin B. Gene expression. 2. Encaryotic chromosome. 2nd ed. New York: John Wiley and Sons, 1980:875-8.

8 Williams MA, Kleinschmidt JA, Krohne G, Franke WW. Argyrophilic nuclear and nucleolar proteins of Xenopus laevis oocytes identified by gel electrophoresis. Exp Cell Res 1982;137:341-51.

9 Busch H. Nucleolar proteins: purification, isolation and functional analyses. In: Huilica LS, ed. Chromosomal non histone protein. Vol IV. Boca Raton, Florida: Chemical Rubber Company Press, 1984:233-86.

10 Ochs RL, Busch H. Further evidence that phosphoprotein $C_{23}$ $(110 \mathrm{KD} / \mathrm{pH} 5 \cdot 1)$ is in nucleolar silver staining protein. $\operatorname{Exp}$
Cell Res 1984;152:260-5.

11 Olson MOJ, Thompson BA. Distribution of proteins among chromatin components of nucleoli. Biochemistry 1983;22:3187-93.

12 Hernandez-Verdun D, Derenzini M, Bouteille M. Relationship between the AgNOR proteins and ribosomal chromatin in situ during drug-induced RNA synthesis inhibition. $J$ Ultrastruct Res 1984;88:55-65.

13 Ploton D, Bobichon H, Adnet J-J. Ultrastructural localization of NOR in nucleoli of human breast cancer tissues using a onestep AgNOR staining method. Biol Cell 1982;43:229-32.

14 Ploton D, Menager M, Adnet J-J. Simultaneous high resolution localization of $\mathbf{A g}-\mathrm{NOR}$ proteins and nucleoproteins in interphasic and mitotic nuclei. Histochem $J$ 1984;16:897-906.

Requests for reprints to: Dr J Crocker, Department of Histopathology, East Birmingham Hospital, Bordesley Green East, Birmingham B9 5ST, England. 